\title{
Bolei Liu
}

\section{Columbia University, U.S.A.}

\section{Book Review}

Khan, Shamus Rahman. 2011. Privilege:

The Making of an Adolescent Elite at St. Paul's School. Princeton, NJ: Princeton University Press

DOI: https://doi.org/10.18778/1733-8077.10.2.08

Shamus Rahman Khan, in the Privilege, delinSeated a panorama of one elite high school, St. Paul's, in the United States. He tried to explain four questions in this book: (1) what the difference between new elite and traditional elite is, (2) how the elites' characteristics were cultivated, (3) how the hierarchy inside elite school was formed, and (4) why diversity did not bring equality.

The text was well organized to answer those questions above. Khan, in the first chapter, introduced the history of St. Paul's School in which "the new elites" were cultivated, and "the old elites" in the history of the United States. He claimed a hypothesis that the transition from the old elites to the new elites does not bring back the equality. With meticulous observation, in the next two chapters, Khan analyzed the everyday lives of the students in St. Paul's, and he concluded how the mentality of the new elites was formed. But, Khan did not regard the new elites as a homogeneous group; in the fourth chapter, he studied the women and black students of the new elites. For him, these minor elites rep- resented the old inequality in the new time, which corresponds to his previous hypothesis. Khan also criticized the new elites group in the fifth chapter, to some extent, that they are indifferent, or even arrogant, to the world around them, and that is how they were distinguished from normal people in the new time.

Through Khan's participant observation in St. Paul's, the most notable characteristic of the new elites in St. Paul's, just like the leisure boy on the cover, is the embodiment of their "at ease" (p. 196). As the society is more open than before, some old-fashioned symbols of elite status, such as fine art and classical music, are accessible to all the society. Therefore, the characteristic of new elites lies not in their different tastes, but in that they can make themselves comfortable, or say "at ease", in any circumstances. The way they get to "at ease," according to the author, is through the cultivating in elite school. In the school, they were taught to "take one's place" by rituals in school (p. 48) and by inequality of status between them and the staff in school (p. 52), by resolving into the hierarchy which made by their senior peers, by being cultivated a sense of audacity for knowledge and the exterior world (p. 161) from their teachers, by being indifferent to high culture, and by the excessive access to high culture in elite schools as St. Paul's (p. 186). Khan also suggested several phenomenon of anomie, in Durkheim's context (1997), in the elite society of St. Paul's, which covered the inequality which was experienced by black students and girls in the school. White students are easier to be at ease than their non-white counterparts, and boys have more advantages than girls to be at ease in school. For these two groups of disadvantaged elites, Khan analyzed that the cause of their plight is that in the whole society both female and black are in disadvantage status, which reflected into the reality in St. Paul's then compelled these students to have to work harder than their peers, which made them not at ease in the school. By these cases, Khan suggests a social fact that "the production of privilege will continue to reproduce inequality while implying that ours is a just world" (p. 199).

Khan, in his book, concentrated on the hidden inequality behind a seemingly "meritocracy" society, including not only the inequality among elites, rising elites, and non-elites but also the inequality of gender and race in the elite group. One of the most impressive parts of Privilege is its cultural analysis on the potential elites. In Privilege, the distinction, in Bourdieu's context, has vanished, but new distinction has been established through the different states of living of people. Khan found that the high culture is no longer the symbol of the elite since they are more accessible to all the society, and wealth does not amount to elite status, ease has become the new symbol of elite. Therefore, the students' indifference of high culture has become the embodiment of elites' at ease.

In conclusion, Khan discussed the paradox of new elites culture in the United States, that is, the surface diversity in elite group does not result in equality. The reasons which lead to this paradox lie in the two macro-level social changes: collectivism society was replaced by individualism society and democratic society displaced aristocratic society of the United States. The former gave rise to the diversity in new elite group, since it enables individuals through striving to rank among elite level, whereas the latter lead to new inequality, since, according to Khan and the concept from Bourdieu (1984), the embodiment of the new elite is ease (p. 197), which was not possessed by those who were not elite before, but just step into elite groups by personal strivings. It is a brilliant part for Khan to bond his observation to the social structure of the United States.

In the Privilege, Khan also would like to delve into the transition of the elites groups. According to him, the distinction between elites and normal people has never been changed, even in a more open society. What has changed was merely the way in which they were distinguished from normal people. For him, these elites are capable of forming their own circle, which is very stable and exclusive. I am basically in agreement with this argument. A more open society means that the opportunities could be fairly distributed to more people but it also means a highly competitive society, and the competition inevitably bring about inequality. The major new 
elites and the old elites are not two distinct generations, instead, they share the same blood lineage, so even if these new elites have to compete with more people today, their resources, which were inherited from their old elite parents, would help them out in the competition. However, the minor new elites, just like the black girl in St. Paul's, could not be comfortable at school while they could get into St. Paul's and get very high scores at school. Therefore, although the open society may be meritocratic nowadays, the elites group still remains aristocratic.

As an ethnographic research, Privilege includes large amounts of observations and interactions with the young elites. However, a crucial question the author did not address is that to what extent these teenage elites could represent their adult counterparts? The adolescent elite might be indifferent to high culture by now, but when they grow up and contact with other elites in formal occasions, the elites seemingly might no longer be indifferent to those culture symbols, then how could we be so sure that these young elites, by that time, will not fall into the old elites' set pattern? In other words, while Khan endeavored to use his cases to illustrate that the students in St. Paul's are the potential elites in the future, Privilege did not cast a strong argument on the transition from adolescent elites to real elites in the society and connecting the phenomenon in an elite school with the social fact in the whole society. However, while with this tiny imperfection, there is no doubt that Privilege, as a creative qualitative research on elite group in the United States, would be widely debated by scholars who are interested in this area.

\section{References}

Bourdieu, Pierre. 1984. Distinction: A Social Critique of the Judgment of Taste. Cambridge, MA: Harvard University Press.
Durkheim, Émile. 1997. Suicide: A Study in Sociology. New York: Free Press. 